\title{
Sustainable Development Behavior in the Eco-Label Business Community
}

\author{
Cristina Bălăceanu ${ }^{1}$, Victoria Gonta ${ }^{2}$, Violeta Radulescu ${ }^{3}$ and Mahdi Tarabeih ${ }^{4 *}$ \\ 1Department of Economics and Economic Policies, Bucharest Dimitrie Cantemir Christian University, Romania \\ 2Faculty of Psychology and Socio-Human Sciences, American University of Moldova, Republic of Moldova \\ 3Department of Economics and Economic Policies, Bucharest University of Economic Studies, Romania \\ 4Faculty of Nursing Sciences, Tel Aviv-Jaffa Academic College, Israel
}

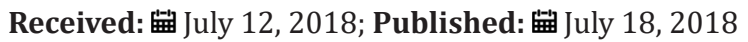

*Corresponding author: Mahdi Tarabeih, Faculty of Nursing Sciences, Tel Aviv-Jaffa Academic College, Jaffa 6818211, Israel,

Email: tarabeih1969@gmail.com

\begin{abstract}
Changing market mechanisms by focusing on clean technologies and reducing the consumption of nonrenewable resources is an objective of the Europe 2020 strategy of the European Commission. Achieving this objective will require not only more restrictive legislation targeting polluting industries and technologies but also the introduction of new models of consumption oriented toward "green" products. Consumers' preferences for nonpolluting products can be enhanced by credible and persuasive marketing instruments, such as the EU Ecolabel. A survey of Romanian businesspeople found that they are aware of the environmental and economic principles underlying the use of eco-labels and are interested in implementing them.
\end{abstract}

Keywords: Behavior; Consumers; Green Marketing; Ecolabel; Clean Technologies; Sustainable Development

\section{Introduction}

Consumers are becoming increasingly aware of the impact of their consumption decisions on the environment and on sustainable development. Today, products are being marketed in a way that both builds on that awareness and takes advantage of consumers' preferences for sustainable development. In fact, consumer research has shown that simply calling a product "eco-friendly" is enough to make people believe it tastes better than an objectively identical alternative and to be willing to pay more for this good. Label effects arise even if there is no reasonable relation between the product label and the product itself. This preference bias for eco-friendly products over objectively identical but conventionally labeled alternatives could be caused by expectation processes that modulate the actual sensory experiences [1]. The incorporation of sustainable development principles into contemporary economic thinking has led to the concept of the circular economy, one that is oriented to reusing waste products. A circular economy, which is built on the recovery and the regeneration of resources, aims to maintain the value and utility of products, components, and raw materials as much as possible. It thereby addresses two major societal and economic issues: the limited nature of resources and the pollution generated by waste. In The Circular Economy: A Wealth of Flows, [2].

argues that the economic reality of the twenty-first century makes necessary the shift away from the "take, make, and dispose" paradigm, which was appropriate for economic mechanisms of the twentieth century, toward organizational models that reflect feedback-rich flows. The former paradigm focuses on maximizing production in order to obtain profit, without determining the impact on the environment with respect to the waste of natural resources. The latter entail a regenerative economy which leads to changes in the occupational structure of human resources and requires new tax policies, both at the national level and globally. This will create new occupations in the field of natural environment, which will generate a rational approach to environmental issues, supplementing jobs that will be lost by increasing the impact of new technology on the labor market. Consumers' purchasing decisions, a key element of those feedback flows, are influenced by an array of psychological, moral, and cultural factors $[3,4]$, in their study of "environmental morale and motivation," argue that individuals are driven by altruism, social norms and reciprocal fairness, internalized norms (in which strong moral principles, contained in the company's code of conduct, induce self-evaluation), and intrinsic motivation (i.e., the willingness to pursue an activity for the benefit it yields in itself).

Individuals' purchasing decisions are influenced not only by their ethical values and beliefs; customs; culture; and social, political, and moral values but also by institutional settings that are likely to shape such attitudes by encouraging or discouraging some 
behaviors and attitudes. Individuals' economic behavior regarding environmental issues is also justified by their civic values. The representation of consumers' environmental preferences through their utility functions should also reflect these multiple noneconomic determinants [5]. Today there are more than 400 labels [6] meant to convey the message to the consumer that the product/ service is eco-friendly. According to a recent study carried within 26 countries worldwide, $86 \%$ consumers are concerned about the impact of climatic changes, and $71 \%$ avoid buying goods that are shipped from a great distance [7]. According to other studies, more than half of consumers want to buy products labeled as eco-friendly or take into consideration social or environmental protection factors when they decide to buy a product. However, they are confused by the multitude of labels / brands touting they are protective of the environment and face the difficulty of deciding which ones they can trust [8].

Because it is hard for consumers themselves to verify whether those products are indeed "green," they usually rely on colabel programs to certify such claims. Typically, these programs certify - in exchange for a fee-that a firm's product meets a given environmental-performance standard determined by the program and then allow the firm to feature that program's eco-label on its packaging or advertising materials [9]. Eco-labels thus help inform consumers of the potential impacts on the environment based on the product's or service's life-cycle considerations $[10,11]$. They can serve as an efficient green marketing tool that links sustainable production to sustainable consumption. To achieve Europe 2020's ambitious targets regarding sustainable development, the EU Ecolabel needs to be supported by robust analysis of the impact of Table 1: Sample structure. green products and services on the environment. Identifying the environmental footprint of products (their product environmental footprint) is not just a more precise tool for measuring the environmental impact of economic activities but also will promote a single market for green products.

Both producers and consumers need easy recognizable criteria to identify and compare products and services according to their impact on the environment, and policies and programs developed within the European Union can have a significant effect in the medium and long term in the development of a sustainable economy. Adopting ecological strategies or creating initiatives consistent with the requirements of sustainable development should also help increase businesses' economic performance [12]. However, the effective implementation of such strategies depends on support from management, an efficient method of production process, and the commitment of resources [13-15]. This study had three research objectives: to determine whether Romanian business people are aware of the environmental and economic principles underlying the use of eco-labels and are interested in implementing them.

\section{Method}

A survey of 234 members of the Romanian business community elicited respondents' views on the ethical, environmental, and economic impact of eco-labels, both those promulgated by the EU and by the Romanian government (Tables 1 \& 2), and their level of interest in using eco-labels. An econometric tool identified statistical correlations in the data (Table 3) and (Figure 1). The effect of eco-labels on economic performance was also examined.

\begin{tabular}{|c|c|c|}
\hline Characteristics & & Percentage of sample \\
\hline & $18-24$ years & 1.20 \\
Age groups of Entrepreneur & $25-34$ & 18.31 \\
& $35-44$ & 66.30 \\
& $35-54$ & 8.24 \\
0.12 & 63.67 \\
\hline Residence & $55-64$ & 26.33 \\
\hline \multirow{2}{*}{ Company* } & Over 64 & 5.25 \\
& Urban area & 78.34 \\
\end{tabular}

Table 2: Survey Questions and Measurement Scale.

\begin{tabular}{|c|c|c|}
\hline Questions & Measurement [1] & Results \\
\hline $\begin{array}{c}\text { In the business partnerships that you develop } \\
\text { are you guided by values that affect the } \\
\text { environment? }\end{array}$ & Very often & 0.61 \\
\hline & Often & 0.25 \\
$\begin{array}{c}\text { In the business partnerships that you develop } \\
\text { are you guided by values that affect the } \\
\text { environment? }\end{array}$ & Very often & 0.61 \\
& Often & 0.25 \\
& Seldom & 0.12 \\
\hline
\end{tabular}




\begin{tabular}{|c|c|c|}
\hline \multirow{5}{*}{$\begin{array}{l}\text { Does the EU legislation on the "Eco label" have } \\
\text { a major influence on your business ethical } \\
\text { behavior? }\end{array}$} & Very often & 0.46 \\
\hline & Often & 0.34 \\
\hline & Seldom & 0.12 \\
\hline & Very seldom & 0.05 \\
\hline & Never & 0.03 \\
\hline \multirow{5}{*}{$\begin{array}{c}\text { Do you believe that there is a degree of } \\
\text { convergence between the EU legislation on } \\
\text { the Ecolabel and national legislation on the } \\
\text { Ecolabel? }\end{array}$} & Very often & 0.37 \\
\hline & Often & 0.35 \\
\hline & Seldom & 0.13 \\
\hline & Very seldom & 0.08 \\
\hline & Never & 0.07 \\
\hline \multirow{5}{*}{$\begin{array}{l}\text { How often do you come in contact with the } \\
\text { following (consumers/local business partners / } \\
\text { foreign business partners/ others) who believe } \\
\text { that the use of the Ecolabel is an opportunity? }\end{array}$} & Very often & 0.42 \\
\hline & Often & 0.38 \\
\hline & Seldom & 0.1 \\
\hline & Very seldom & 0.08 \\
\hline & Never & 0.07 \\
\hline \multirow{5}{*}{$\begin{array}{l}\text { Do you consider that the Ecolabel encourages } \\
\text { businesses to market goods and services with } \\
\text { low environmental impact? }\end{array}$} & Very often & 0.47 \\
\hline & Often & 0.3 \\
\hline & Seldom & 0.12 \\
\hline & Very seldom & 0.06 \\
\hline & Never & 0.05 \\
\hline \multirow{5}{*}{$\begin{array}{l}\text { Do you consider that the Ecolabel helps people } \\
\text { easily identify organic products and services? }\end{array}$} & Very often & 0.63 \\
\hline & Often & 0.23 \\
\hline & Seldom & 0.08 \\
\hline & Very seldom & 0.04 \\
\hline & Never & 0.03 \\
\hline \multirow{5}{*}{$\begin{array}{l}\text { Do you consider that the Ecolabel promotes } \\
\text { products that have a low environmental impact? }\end{array}$} & Very often & 0.52 \\
\hline & Often & 0.3 \\
\hline & Seldom & 0.09 \\
\hline & Very seldom & 0.02 \\
\hline & Never & 0.03 \\
\hline \multirow{5}{*}{$\begin{array}{l}\text { Are you subjected to pressures by EU to accept } \\
\text { the principles of the Ecolabel? }\end{array}$} & Very often & 0.28 \\
\hline & Often & 0.25 \\
\hline & Seldom & 0.24 \\
\hline & Very seldom & 0.05 \\
\hline & Never & 0.06 \\
\hline \multirow{5}{*}{$\begin{array}{l}\text { Do your partners respect your ethical principles } \\
\text { of environment protection? }\end{array}$} & Very often & 0.4 \\
\hline & Often & 0.4 \\
\hline & Seldom & 0.11 \\
\hline & Very seldom & 0.04 \\
\hline & Never & 0.05 \\
\hline \multirow{5}{*}{$\begin{array}{l}\text { Do you make an effort to protect the } \\
\text { environment? }\end{array}$} & Very often & 0.3 \\
\hline & Often & 0.33 \\
\hline & Seldom & 0.22 \\
\hline & Very seldom & 0.06 \\
\hline & Never & 0.09 \\
\hline
\end{tabular}


Do you think that the excessive consumption of goods tends to be seen as a possible danger for nature because it can lead to the degeneration of environment?

\begin{tabular}{c|c} 
Very often & 0.62 \\
Often & 0.2 \\
Seldom & 0.09 \\
Very seldom & 0.05 \\
Never & 0.04 \\
\hline
\end{tabular}

Table 3: Model Statistics.

\begin{tabular}{|c|c|c|c|c|c|c|}
\hline Model & $\begin{array}{c}\text { Number of } \\
\text { Predictors }\end{array}$ & Model Fit statistics & Ljung-Box Q (18) & Number of Outliers & Sig. \\
\hline & & $\begin{array}{c}\text { Stationary } \\
\text { R-squared }\end{array}$ & Statistics & DF & 1 \\
\hline Q1-Model_1 & 1 & 1.008 & 2.832 & 18 & 0 \\
\hline Q2-Model_2 & 0 & $2.78 \mathrm{E}-15$ & 1.879 & 18 & 1 \\
\hline Q3-Model_3 & 0 & $4.22 \mathrm{E}-15$ & 2.163 & 18 & 1 \\
\hline Q4-Model_4 & 0 & $3.00 \mathrm{E}-15$ & 2.002 & 18 & 0 \\
\hline Q5-Model_5 & 1 & 1.008 & 8.536 & 18 & 0.97 \\
\hline Q7-Model_6 & 2 & 1.468 & 21.361 & 18 & 0 \\
\hline Q8-Model_7 & 1 & 1.031 & 2.501 & 18 & 0 \\
\hline Q9-Model_9 & 1 & 1.046 & 9.495 & 18 & 0 \\
\hline
\end{tabular}

Summary of the Fit statistics model, ANOVA, used to analysis the variance between factors.

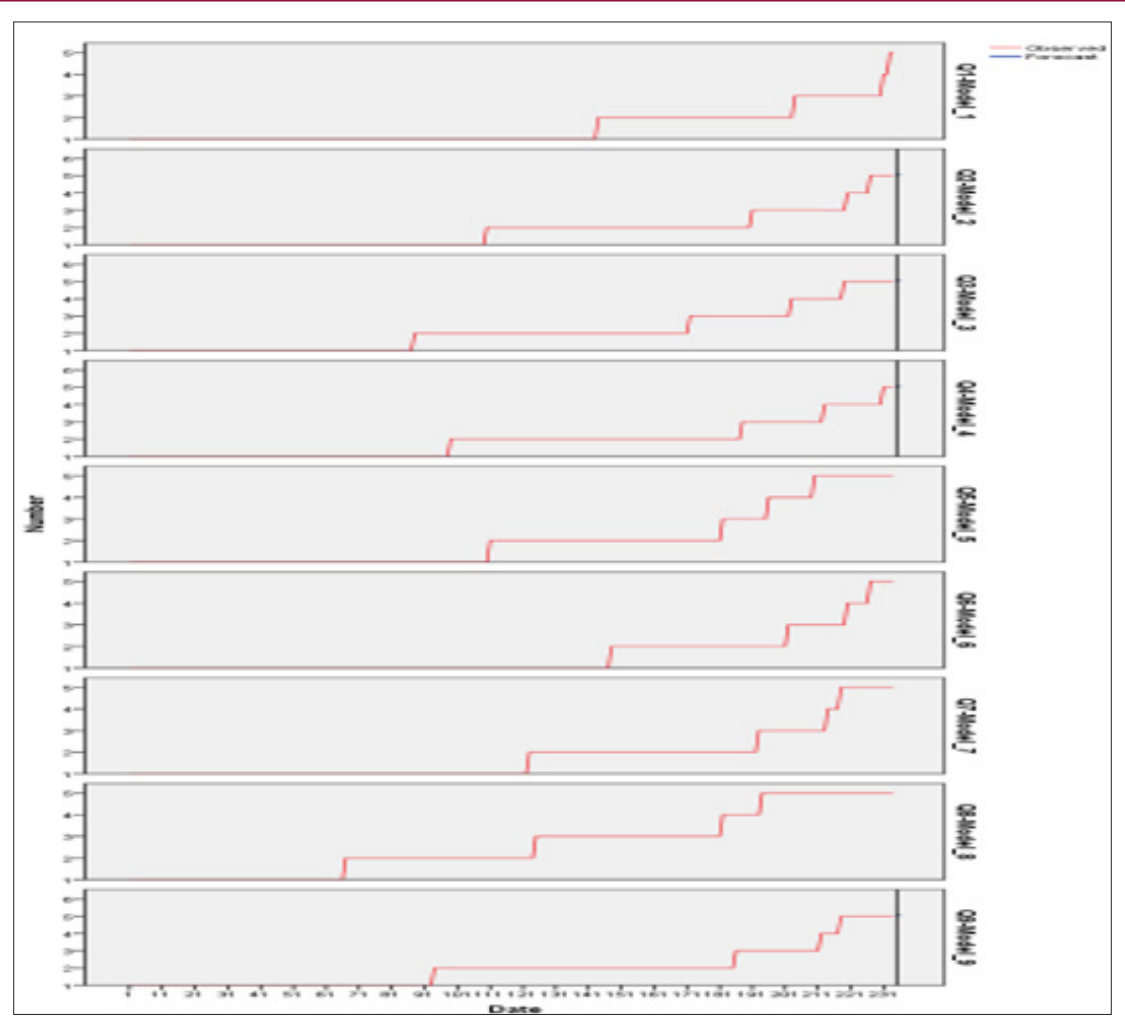

Figure 1: Correlation analysis of Q1-Q9 compounds using cluster diagram

\section{Analysis of Data}

This research used a multiple regression analysis with a 16-coded categorical predictor with interaction. We analyze a covariance demonstration using ANOVA with five categorical factors for each of 11 questions.

\section{Results}

The survey data show that the business agents are interested in implementing eco-labels because they believe that doing so will not only yield increased economic performance but also support sustainable development of the economy. Care for the environment 
has become a norm of corporate social responsibility, which is equated to the production and promotion of environmentally labeled products among consumers. The results confirm both the interest of business agents in using eco-labels and their positive attitudes to the environmental principles underlying their use, as shown in the performance indicators in all the Q1-Q9 models, especially the Q3 model. Within this model, the variable Q1 is the dependent variable, and Q1-Q3 are representative of the model. The stationary R-squared indicator compares the stationary part of the model to a simple mean model. This measure is preferable to ordinary R-squared when there is a trend or seasonal pattern. Stationary R-squared positive values of the stationary R-squared mean that the model under consideration is better than the baseline model. From the results, we can see that Q3 has the highest positive value: stationary R-squared $=4.219 \mathrm{E}-015$. Column $\mathrm{DF}$ lists the degrees of freedom for each of the tests of the coefficients. There is one degree of freedom for each predictor in the model. In this example, we have 16 predictors.

\section{Conclusion}

Both at the micro- and macroeconomic level, a new vision of economic efficiency should be promoted that links investment in sustainable production with reduction in generated waste and in the costs of managing that waste [4]. The EU Ecolabel can be a valuable tool in the implementation of that vision: it can facilitate sustainable development and serve as a green marketing strategy in an information-oriented society. Decoupling economic growth from environmental degradation and the use of nonrenewable resources requires not only legislation aimed at penalizing polluters but also tools that stimulate the production and consumption of environmentally friendly goods through marketing mechanisms. By identifying how any product / service relates to clear criteria of environmental protection, the EU Ecolabel is key to the success of the Europe-wide project to promote sustainable development principles and implement green marketing. Ecolabels with sustainability claims are now emerging worldwide. For the EU Ecolabel to be effective as a marketing tool for sustainable development, the criteria used to determine whether products indeed merit that label need to be strategically developed and communicated clearly. Such labeling programs should include and communicate all aspects related to sustainability in the production processes [4]. The criteria development process and effective communication of those criteria are the core elements of effective eco-labeling programs. This study shows the high level of interest among Romanian business people in implementing the EU Ecolabel as part of a sustainable production cycle. Its use will not only promote the rational use of resources and sustainable business development but also may increase market share.

\section{References}

1. Sörqvist P, Haga A, Langeborg L, Holmgren M, Wallender M, et al. (2015) The green halo: Mechanisms and limits of the eco-label effect. Food Quality and Preference 43: 1-9.

2. Webster K (2015) The circular economy: A wealth of flows. Isle of Wight, UK: Ellen MacArthur Foundation.

3. Radulescu DM, Radulescu V (2011) Educating the consumer about his right to a healthy environment. Procedia-Social and Behavioral Sciences 15: $466-470$.

4. Frey BS, Stutzer A (2006) Environmental morale and motivation. In A. Lewis (Eds), Cambridge Handbook of Psychology and Economic Behavior, Cambridge: Cambridge University Press 20:18.

5. Chakori Sabrina (2017) Builing a sustainable society: the necessity to change the term of "consumer", in Interdisciplinary Journal of Partnership studies 4(3).

6. Zengwei Y, Jun B, Moriguichi Y (2008) The circular economy: A new development strategy in China. Journal of Industrial Ecology 10(1-2): 4-8.

7. Farmer REA (2012) The evolution of endogenous business cycles. Hong Kong Institute for Monetary Research.

8. Paquot Sébastien (2017) Moving towards a circular economy with EMAS, Best practices to implement circular economy strategies (with case study examples), European Commission-DG EnvironmentSustainable Production, Products \& Consumtion, European Commission, Luxembourg: Publications Office of the European Union.

9. Li Y, Veld KT (2015) Green, greener, greenest: Eco-label gradation and competition. Journal of Environmental Economics and Management 72: 164-176.

10. Monteiro JA (2010) Eco-label adoption in an interdependent world (IRENE Working Papers, No.10-01). Neuchâtel, IRENE Institute of Economic Research, Switzerland.

11. Phenga LS, Shang G, Long SY (2014) Strategies and measures for implementing eco-labeling schemes in Singapore's construction industry. Resources, Conservation and Recycling 89: 31-40.

12. Chan RK, He H, Chan H, Wang WCE (2012) Environmental orientation and corporate performance: The mediation mechanism of green supply chain management and moderating effect of competitive intensity, Industrial Marketing Management 41(4): 621-630.

13. Richey RG, Musgrove C, Gillison S, Gabler C (2014) The effects of environmental focus and program timing on green marketing performance and the moderating role of resource commitment. Industrial Marketing Management 43(7): 1246-1257.

14. Radulescu DM, Radulescu V (2012) Ecological responsibility-part of sustainable development. International Journal of Academic Research in Economics and Management Science 1(8): 89-96.

15. Gooch G, Williams M (2007) A dictionary of law enforcement. Oxford: Oxford University Press, USA. 
ISSN: 2574-1241

DOI: 10.26717/BJSTR.2018.07.001438

Mahdi Tarabeih. Biomed J Sci \& Tech Res

(C) This work is licensed under Creative

Submission Link: https://biomedres.us/submit-manuscript.php

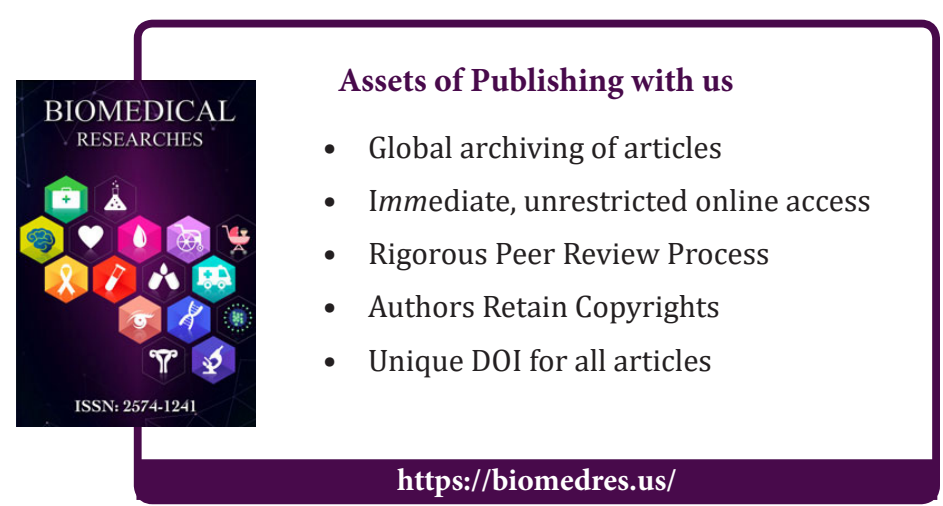

